\title{
A Prototype Web-Based Emergency Response System That Incorporates the Findings from the Shortest Route Techniques for Path Optimization
}

\author{
Olawale J. Omotosho, Charles Okonji*, Ogbonna, A. C., Sodiya Adesina
}

\begin{abstract}
This paper holistically reviewed the present emergency response operations of the Lagos State Emergency Management Authority (LASEMA), and identified deficiencies. This ultimately led to the development of an improved network, premised on the assumption that all the response management sub-stations (LRU) of LASEMA in Lagos State were networked to a central location where all command operations are easily disseminated. An improved framework was then designed, that utilised an improved Ant Colony Optimization technique layered on the Google Map functionality to determine the shortest route to an incident site for the emergency vehicle conveying the first responders to the incident site. A detailed discussion on the design, development, implementation and evaluation approaches used for the Emergency Response Management System (ERMS) was done. How data used in this work were collected, tested for quality of its contents and then analysed using the descriptive analysis of the Statistical Package for Social Sciences (SPSS) software was extensively discussed.

Also, the data collected before and after the implementation of the developed Emergency Response Management System (ERMS) were analysed using the descriptive analysis of the SPSS software, as to measure the perceived performance of the system, based on the variables defined from the Technology Acceptance Model (TAM). From the analyses of the results of these metrics, we concluded that the ERMS was able
\end{abstract}

Manuscript received March 21, 2020

Olawale J. Omotosho, Computer Science Department, Babcock University, Ilishan-Remo, Nigeria

Charles Okonji, Computer Science Department, Babcock University, Ilishan-Remo, Nigeria (email: charles_okonji@yahoo.co.uk )

Ogbonna, A. C., Computer Science Department, Babcock University, Ilishan-Remo, Nigeria

Sodiya Adesina, Computer Science Department, Babcock University, Ilishan-Remo, Nigeria to optimise routes, provided for timely and accurate provisioning of emergency resources for effective disaster response operations; and also improved serviceability and efficiency existing emergency response operations by LASEMA.

KEYWORDS- Emergency Response Management System, Technology Acceptance Model, Ant Colony Optimization algorithm, Lagos State Emergency

\section{INTRODUCTION}

Delayed responses to emergency management in disaster situations continue to result in enormous losses of lives and properties in developing countries. This situation is, in part, a consequence of absent strategic approaches to disaster management, and the inability to harness the capacity of innovative technological solutions to overcome the domestic challenges that prove inimical to effective disaster response in these regions. Amongst these challenges have been the problem of poor communication infrastructure and ground navigation capabilities, and lack of detailed and timely first responder evaluations that hamper effective and accurate resource provisioning in disaster situations. It is in light of these lingering challenges that this research developed an Emergency Response Management System (ERMS) that integrates the capabilities of Information and Communication Technologies (ICT) towards effective disaster response in developing countries.

In this work, the issue concerning the lack of interconnectivity between these response management substations was addressed with a framework that premised on a Control Room inter-linked to these sub-stations, provide instant information on the most likely equipment to deploy for further reducing the likely losses to lives and properties, and on the best route for the first responders in locating the incident site. Knowing that time is a very critical element in every emergency response operation, the

Framework designed in this research helps to mitigate against further losses of lives and properties since the first responders would now arrive at incident sites faster and with the required equipment. In addition, the Response Unit 


\section{A Prototype Web-Based Emergency Response System That Incorporates the Findings from the Shortest Route Techniques for Path Optimization}

nearest to the incident site would be put on immediate alert, to provide some degree of mitigation support until the full deployment of resources from an Operation Control center. In this work, 4 short path algorithms (Ant Colony Optimization (ACO), Dijkstra, Bellman Ford, and Suurballe) were used and implemented in the developed ERMS, to determine which offers the fastest response time as first responders [12] are deployed to an incident location. The Ant Colony Optimization algorithm [1, 2, 3, 5, 7, 8, 10, 11] proved the best of them, as its response time was the smallest. The developed system was a composite of a frontend mobile application that runs on Android smartphones and a back-end web-based server application. Running the front end application on mobile phones [6, 13] ensures ease pf mobility and instant information dissemination.

To measure the level of acceptance of the new emergency response system, a questionnaire was designed based on some questions derived from the Technology Acceptance Model (TAM). This TAM model [4] is often used in instances when the performance of an information system could not be easily measured.

\section{METHODOLOGY}

The presence emergency response system in LASEMA of Lagos State is more of manual than large-scale use of Information and Communication Technology. (ICT). At present, the public will send information through a dedicated hotline telephone number to the agency's Control Room. From this room, a dispatch rider will ride on a motor bike to the incident site, to do an eye witness situation reporting. The information from the rider next determines the first responders from the nearest response unit station (LRU) to the incident site to deploy to site, and often with equipment that may not achieve desired results. Therefore, a framework that assumes a wide area connectivity of all response unit sub-stations to the central Control Room is developed, such that information dissemination becomes easier. The framework is then automated as an emergency response management system (ERMS) which is a composite of a mobile application at the front-end and a web-based server application at the backend. In this instance, when a disaster occurs, the public can result the incident to the LASEMA Control Room through this mobile application. Information will then be processed at the server application, to provide details of the best route of travel for first responders and a combination of likely equipment to deploy to site (Figure 1).
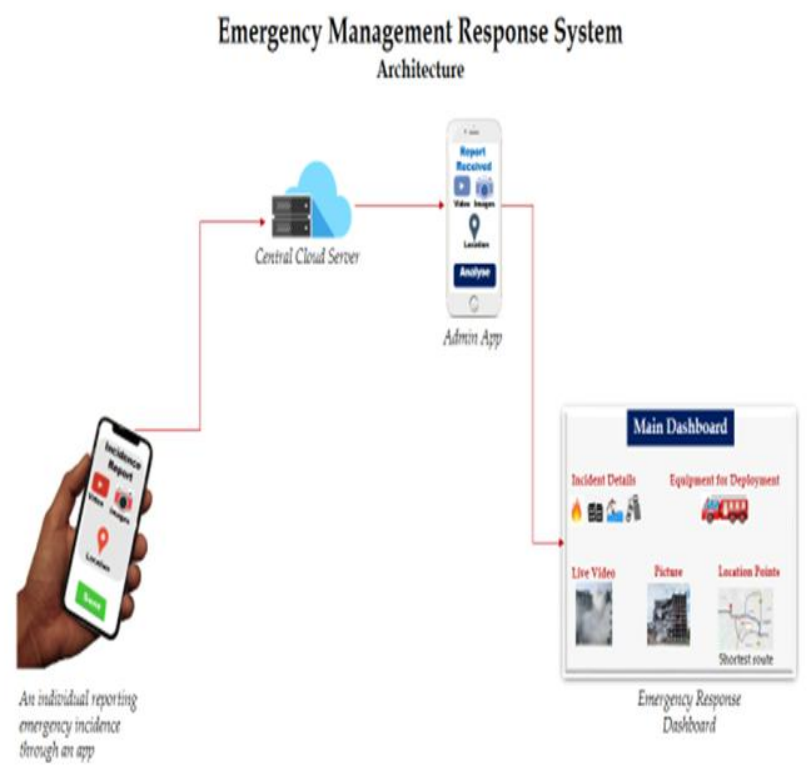

Figure 1: Emergency Management Response System Framework

All information about the best travel route for first responders and likely equipment to deploy to incident site, are displayed through a dashboard at the server application backend. Figure 2 shows this dashboard.

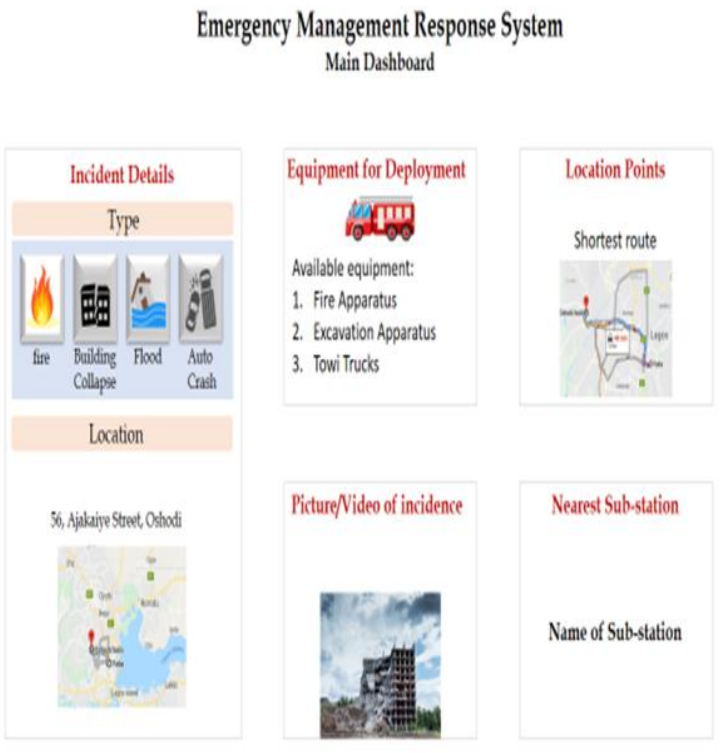

Figure 2: Back-end Server System Dashboard

The implementation phase of the new emergency response management system (ERMS) was conducted in phases based on 4 short path algorithms (Ant Colony Optimization (ACO), Dijkstra, Bellman Ford, and Suurballe). At each phase, a unique short path algorithm was used to measure the time it takes the first responders to get to an incident location. These response time values were then compared, 
and this comparison showed the Ant Colony Optimization (ACO) algorithm as offering the shortest travel time.

In addition, an evaluation of the performance of the new ERMS was done using the Technology Acceptance Model (TAM) to measures its level of acceptance by the likely users. The measurement metrics used were Perceived Ease of Use (PEU), Perceived Usefulness (PU), Perceived Attitudes Towards Use (PATU), Perceived Behavioural Intention to Use (PBIU), and lastly the Perceived Job Relevance (PJR) of the ERMS. A structured questionnaire with questions drawn to address these metrics was designed and deployed on 2 occasions. The first time was at the pretest level, when a select group of core operations employees of LASEMA used the contents of the questionnaire to assess the current emergency response system in place and then, during post-test, when the new system was implemented and the employees made to again, use the questionnaire to assess the level of acceptance of this new emergency response system. For each test, the descriptive analysis of the Statistical Package for the Social Sciences (SPSS) was used to describe the outcomes, based on Frequencies, Mean and Percentages. A test for any variation between the outcomes from both the pre-test and the posttest was evaluated using the T-test statistics. For a sample size of 87 respectively for the Control Group and the Experimental Group, during pre-test, all responded to the questionnaire deployed to access their levels of acceptance of the current emergency response system in place at LASEMA. However, during post-test, only 64 out of the 87 possible respondents for the Experimental Group filled the questionnaire deployed to access the new emergency response system after its implementation, for level of acceptance. Table 1 and Table 2 provide an analysis of the response rates and the socio-demographic characteristics of these respondents.

Table 1: Respondents' Response Rate

(Source: Researcher's Field Results, 2020)

\begin{tabular}{|l|l|l|}
\hline Sample Size & Number & Percentage (\%) \\
\hline $\begin{array}{l}\text { Pre-test (Control } \\
\text { Group) }\end{array}$ & 87 & 100 \\
\hline $\begin{array}{l}\text { Pretest } \\
\text { (Experimental } \\
\text { Group) }\end{array}$ & 87 & 100 \\
\hline $\begin{array}{l}\text { Post-test (Control } \\
\text { Group) }\end{array}$ & 87 & 100 \\
\hline $\begin{array}{l}\text { Post-test } \\
\text { (Experimental } \\
\text { Group) }\end{array}$ & 64 & 73.5 \\
\hline
\end{tabular}

Table 2: Socio-Demographic Characteristics of Respondents: (Source: Researcher's Field Results, 2020)

\begin{tabular}{|c|c|c|c|}
\hline Variables & Options & Frequency & $\begin{array}{l}\text { Percentage } \\
(\%)\end{array}$ \\
\hline \multirow[t]{2}{*}{ Gender } & Male & 45 & 70.31 \\
\hline & Female & 19 & 29.69 \\
\hline \multirow[t]{6}{*}{ Age } & $18-25$ & 2 & 3.13 \\
\hline & $26-31$ & 10 & 15.63 \\
\hline & $32-38$ & 15 & 23.44 \\
\hline & $39-45$ & 13 & 20.31 \\
\hline & $46-49$ & 12 & 18.75 \\
\hline & $\begin{array}{l}50 \text { years and } \\
\text { above }\end{array}$ & 12 & 18.75 \\
\hline \multirow{5}{*}{$\begin{array}{l}\text { Highest } \\
\text { Educational } \\
\text { Qualification }\end{array}$} & Secondary & 6 & 9.38 \\
\hline & Diploma & 8 & 12.50 \\
\hline & $\begin{array}{l}\text { Graduate } \\
\text { (HND/B.Sc) } \\
\text { Degrees }\end{array}$ & 29 & 45.31 \\
\hline & $\begin{array}{l}\text { Post- } \\
\text { Graduate } \\
\text { Degrees }\end{array}$ & 9 & 14.06 \\
\hline & $\begin{array}{l}\text { Professional } \\
\text { Degree }\end{array}$ & 12 & 18.75 \\
\hline \multirow[t]{4}{*}{ Job Position } & Manager & 5 & 7.81 \\
\hline & Supervisor & 14 & 21.88 \\
\hline & $\begin{array}{l}\text { Dispatch } \\
\text { Riders } \\
\end{array}$ & 15 & 23.44 \\
\hline & $\begin{array}{l}\text { Field } \\
\text { Operator }\end{array}$ & 30 & 46.88 \\
\hline \multirow[t]{6}{*}{ Locations } & Igando & 10 & 15.63 \\
\hline & Ikorodu & 8 & 12.50 \\
\hline & Lekki & 5 & 7.81 \\
\hline & Onipanu & 7 & 10.94 \\
\hline & $\begin{array}{l}\text { Cappa- } \\
\text { Oshodi }\end{array}$ & 14 & 21.88 \\
\hline & Alausa-Ikeja & 20 & 31.25 \\
\hline
\end{tabular}

The responses of the 64 respondents after system implementation for the Experimental Group were as reported for each TAM metric in Tables 3, 4, 5, 6, and 7 respectively. 


\section{A Prototype Web-Based Emergency Response System That Incorporates the Findings from the Shortest Route Techniques for Path Optimization}

Table 3: Descriptive Analysis of Perceived Ease of Use of the ERMS

(Source: Researcher's Field Results, 2020)

\begin{tabular}{|c|c|c|c|c|c|c|}
\hline $\mathbf{S} / \mathbf{N}$ & Statements & $\begin{array}{c}\text { SA } \\
\mathbf{N} \\
(\%)\end{array}$ & $\begin{array}{c}\mathbf{A} \\
\mathbf{N} \\
(\boldsymbol{\%})\end{array}$ & $\begin{array}{c}\mathrm{D} \\
\mathbf{N} \\
(\%)\end{array}$ & $\begin{array}{l}\text { SD } \\
\text { N } \\
(\%)\end{array}$ & Mean \\
\hline 1. & $\begin{array}{l}\text { I perceive that the use } \\
\text { of ERMS would be } \\
\text { easy for me }\end{array}$ & $\begin{array}{c}52 \\
81.3\end{array}$ & $\begin{array}{c}10 \\
15.6\end{array}$ & $\begin{array}{c}2 \\
3.1\end{array}$ & $\begin{array}{l}0 \\
0\end{array}$ & 3.8 \\
\hline 2. & $\begin{array}{l}\text { My interaction with } \\
\text { ERMS was clear and } \\
\text { understandable }\end{array}$ & $\begin{array}{c}36 \\
56.3\end{array}$ & $\begin{array}{c}28 \\
43.8\end{array}$ & $\begin{array}{l}0 \\
0\end{array}$ & $\begin{array}{l}0 \\
0\end{array}$ & 3.6 \\
\hline 3. & $\begin{array}{l}\text { I feel that it would be } \\
\text { easy to become skillful } \\
\text { after using ERMS }\end{array}$ & $\begin{array}{c}46 \\
71.9\end{array}$ & $\begin{array}{c}18 \\
28.1\end{array}$ & $\begin{array}{l}0 \\
0\end{array}$ & $\begin{array}{l}0 \\
0\end{array}$ & 3.7 \\
\hline 4. & $\begin{array}{l}\text { Learning to operate the } \\
\text { ERMS was easy for me }\end{array}$ & $\begin{array}{c}52 \\
81.3\end{array}$ & $\begin{array}{c}8 \\
12.5\end{array}$ & $\begin{array}{c}4 \\
6.3\end{array}$ & $\begin{array}{l}0 \\
0\end{array}$ & 3.8 \\
\hline 5. & $\begin{array}{l}\text { I find it easy to use the } \\
\text { ERMS to achieve my } \\
\text { desired goals }\end{array}$ & $\begin{array}{c}50 \\
78.1\end{array}$ & $\begin{array}{c}12 \\
18.8\end{array}$ & $\begin{array}{c}2 \\
3.1\end{array}$ & $\begin{array}{l}0 \\
0\end{array}$ & 3.8 \\
\hline 6. & $\begin{array}{l}\text { I feel that my ability to } \\
\text { use ERMS is due to my } \\
\text { experience on the field } \\
\text { as a staff of LASEMA }\end{array}$ & $\begin{array}{c}40 \\
62.5\end{array}$ & $\begin{array}{c}20 \\
31.3\end{array}$ & $\begin{array}{c}4 \\
6.3\end{array}$ & $\begin{array}{l}0 \\
0\end{array}$ & 3.6 \\
\hline 7. & $\begin{array}{l}\text { My ability to use the } \\
\text { ERMS easily was } \\
\text { constrained by its } \\
\text { complex user interface }\end{array}$ & $\begin{array}{c}44 \\
68.8\end{array}$ & $\begin{array}{c}20 \\
31.3\end{array}$ & $\begin{array}{l}0 \\
0\end{array}$ & $\begin{array}{l}0 \\
0\end{array}$ & 3.7 \\
\hline 8. & $\begin{array}{l}\text { Using the ERMS } \\
\text { helped greatly to } \\
\text { reduce the response } \\
\text { time to any disaster } \\
\text { incident }\end{array}$ & $\begin{array}{c}58 \\
90.6\end{array}$ & $\begin{array}{c}4 \\
6.25\end{array}$ & $\begin{array}{c}2 \\
3.1\end{array}$ & $\begin{array}{l}0 \\
0\end{array}$ & 3.9 \\
\hline 9. & $\begin{array}{l}\text { The ERMS unlike } \\
\text { other similar systems, } \\
\text { help to mitigate against } \\
\text { losses to lives and } \\
\text { properties }\end{array}$ & $\begin{array}{c}54 \\
84.4\end{array}$ & $\begin{array}{c}8 \\
12.5\end{array}$ & $\begin{array}{c}2 \\
3.1\end{array}$ & $\begin{array}{l}0 \\
0\end{array}$ & 3.8 \\
\hline 10 & $\begin{array}{l}\text { My interaction with } \\
\text { ERMS is clear and } \\
\text { understandable }\end{array}$ & $\begin{array}{c}56 \\
87.5\end{array}$ & $\begin{array}{c}8 \\
12.5\end{array}$ & $\begin{array}{l}0 \\
0\end{array}$ & $\begin{array}{l}0 \\
0\end{array}$ & 3.9 \\
\hline 11 & $\begin{array}{l}\text { I perceive that the use } \\
\text { of ERMS would be } \\
\text { easy for me }\end{array}$ & $\begin{array}{c}42 \\
65.6\end{array}$ & $\begin{array}{c}18 \\
28.1\end{array}$ & $\begin{array}{c}4 \\
6.3\end{array}$ & $\begin{array}{l}0 \\
0\end{array}$ & 3.6 \\
\hline
\end{tabular}


Table 4: Descriptive Analysis of Perceived Usefulness of the ERMS

(Source: Researcher's Field Results, 2020)

\begin{tabular}{|c|c|c|c|c|c|c|}
\hline S/N & Statements & $\begin{array}{l}\mathbf{S A} \\
\mathbf{N} \\
(\%)\end{array}$ & $\begin{array}{l}\mathbf{A} \\
\mathbf{N} \\
(\%)\end{array}$ & $\begin{array}{l}\mathbf{D} \\
\mathrm{N} \\
(\%)\end{array}$ & $\begin{array}{l}\text { SD } \\
\text { N } \\
(\%)\end{array}$ & Mean \\
\hline 1. & $\begin{array}{l}\text { I perceive that using ERMS has } \\
\text { enable me to accomplish my task } \\
\text { more effectively }\end{array}$ & $\begin{array}{l}56 \\
87.5\end{array}$ & $\begin{array}{l}4 \\
6.25\end{array}$ & $\begin{array}{l}4 \\
6.3\end{array}$ & $\begin{array}{l}0 \\
0\end{array}$ & 3.8 \\
\hline 2. & $\begin{array}{l}\text { Using the ERMS has improved my } \\
\text { responsiveness level on disaster }\end{array}$ & $\begin{array}{l}36 \\
56.3\end{array}$ & $\begin{array}{l}28 \\
43.8\end{array}$ & $\begin{array}{l}0 \\
0\end{array}$ & $\begin{array}{l}0 \\
0\end{array}$ & 3.6 \\
\hline 3. & $\begin{array}{l}\text { The use of ERMS enhanced my } \\
\text { understanding of how to minimize } \\
\text { the }\end{array}$ & $\begin{array}{l}54 \\
84.4\end{array}$ & $\begin{array}{l}10 \\
15.6\end{array}$ & $\begin{array}{l}0 \\
0\end{array}$ & $\begin{array}{l}0 \\
0\end{array}$ & 3.8 \\
\hline 4. & $\begin{array}{l}\text { Using ERMS made it easier to notify } \\
\text { the concerned emergency response } \\
\text { management authority about a } \\
\text { disaster }\end{array}$ & $\begin{array}{l}52 \\
81.3\end{array}$ & $\begin{array}{l}8 \\
12.5\end{array}$ & $\begin{array}{l}4 \\
6.3\end{array}$ & $\begin{array}{l}0 \\
0\end{array}$ & 3.8 \\
\hline 5. & $\begin{array}{l}\text { Due to its usefulness, I recommend } \\
\text { ERMS as a useful tool in the } \\
\text { Nigerian society, in general }\end{array}$ & $\begin{array}{l}34 \\
53.1\end{array}$ & $\begin{array}{l}28 \\
43.8\end{array}$ & $\begin{array}{l}2 \\
3.1\end{array}$ & $\begin{array}{l}0 \\
0\end{array}$ & 3.5 \\
\hline 6. & $\begin{array}{l}\text { With the use of ERMS, the impact of } \\
\text { disasters in my society will be } \\
\text { mitigated }\end{array}$ & $\begin{array}{l}40 \\
62.5\end{array}$ & $\begin{array}{l}20 \\
31.3\end{array}$ & $\begin{array}{l}4 \\
6.3\end{array}$ & $\begin{array}{l}0 \\
0\end{array}$ & 3.6 \\
\hline 7. & $\begin{array}{l}\text { Overall, I feel that the ERMS is } \\
\text { useful to me }\end{array}$ & $\begin{array}{l}42 \\
65.6\end{array}$ & $\begin{array}{l}20 \\
31.3\end{array}$ & $\begin{array}{l}2 \\
3.1\end{array}$ & $\begin{array}{l}0 \\
0\end{array}$ & 3.6 \\
\hline
\end{tabular}

Table 5 Descriptive Analysis of Perceived Attitudes towards the Use of the ERMS (Source: Researcher's Field Results, 2020)

\begin{tabular}{|c|c|c|c|c|c|c|}
\hline $\mathbf{S} / \mathbf{N}$ & Statements & $\begin{array}{l}\text { SA } \\
\mathbf{N} \\
(\%)\end{array}$ & $\begin{array}{l}\mathbf{A} \\
\mathbf{N} \\
(\%)\end{array}$ & $\begin{array}{l}\mathbf{D} \\
\mathbf{N} \\
(\%)\end{array}$ & $\begin{array}{l}\text { SD } \\
\mathbf{N} \\
(\%)\end{array}$ & Mean \\
\hline 1. & $\begin{array}{l}\text { After it use, I am excited to use } \\
\text { the ERMS always }\end{array}$ & $\begin{array}{l}56 \\
87.5\end{array}$ & $\begin{array}{l}8 \\
12.5\end{array}$ & $\begin{array}{l}0 \\
0\end{array}$ & $\begin{array}{l}0 \\
0\end{array}$ & 3.9 \\
\hline 2. & $\begin{array}{l}\text { I felt comfortable using the } \\
\text { ERMS }\end{array}$ & $\begin{array}{l}48 \\
75\end{array}$ & $\begin{array}{l}16 \\
25\end{array}$ & $\begin{array}{l}0 \\
0\end{array}$ & $\begin{array}{l}0 \\
0\end{array}$ & 3.8 \\
\hline 3. & $\begin{array}{l}\text { I liked the idea of using } \\
\text { ERMS }\end{array}$ & $\begin{array}{l}54 \\
84.4\end{array}$ & $\begin{array}{l}10 \\
15.6\end{array}$ & $\begin{array}{l}0 \\
0\end{array}$ & $\begin{array}{l}0 \\
0\end{array}$ & 3.8 \\
\hline 4. & $\begin{array}{l}\text { After using it, I do not think using the } \\
\text { ERMS is a good idea }\end{array}$ & $\begin{array}{l}52 \\
81.3\end{array}$ & $\begin{array}{l}12 \\
18.8\end{array}$ & $\begin{array}{l}0 \\
0\end{array}$ & $\begin{array}{l}0 \\
0\end{array}$ & 3.8 \\
\hline 5. & I felt anxious while using the ERMS & $\begin{array}{l}50 \\
78.1\end{array}$ & $\begin{array}{l}14 \\
21.9\end{array}$ & $\begin{array}{l}0 \\
0\end{array}$ & $\begin{array}{l}0 \\
0\end{array}$ & 3.8 \\
\hline 6. & $\begin{array}{l}\text { Due to its usefulness, I have some } \\
\text { positive attitudes towards using the } \\
\text { ERMS }\end{array}$ & $\begin{array}{l}40 \\
62.5\end{array}$ & $\begin{array}{l}24 \\
37.5\end{array}$ & $\begin{array}{l}0 \\
0\end{array}$ & $\begin{array}{l}0 \\
0\end{array}$ & 3.6 \\
\hline
\end{tabular}




\section{A Prototype Web-Based Emergency Response System That Incorporates the Findings from the Shortest Route Techniques for Path Optimization}

Table 6 Descriptive Analysis of Perceived Behavioral Intention to Use the ERMS (Source: Researcher's Field Results, 2020)

\begin{tabular}{|c|c|c|c|c|c|c|}
\hline $\mathbf{S} / \mathbf{N}$ & Statements & $\begin{array}{l}\text { SA } \\
\text { N } \\
(\%)\end{array}$ & $\begin{array}{l}\mathbf{A} \\
\mathbf{N} \\
(\%)\end{array}$ & $\begin{array}{l}\mathbf{D} \\
\mathbf{N} \\
(\%)\end{array}$ & $\begin{array}{l}\text { SD } \\
\mathbf{N} \\
(\%)\end{array}$ & Mean \\
\hline 1. & $\begin{array}{l}\text { I am inclined to using the ERMS } \\
\text { due to its inherent benefits }\end{array}$ & $\begin{array}{l}56 \\
87.5\end{array}$ & $\begin{array}{l}8 \\
12.5\end{array}$ & $\begin{array}{l}0 \\
0\end{array}$ & $\begin{array}{l}0 \\
0\end{array}$ & 3.88 \\
\hline 2. & $\begin{array}{l}\text { I intend to use the ERMS in the } \\
\text { future }\end{array}$ & $\begin{array}{l}44 \\
68.8\end{array}$ & $\begin{array}{l}20 \\
31.3\end{array}$ & $\begin{array}{l}0 \\
0\end{array}$ & $\begin{array}{l}0 \\
0\end{array}$ & 3.69 \\
\hline 3. & I do not intend to use the ERMS & $\begin{array}{l}54 \\
84.4\end{array}$ & $\begin{array}{l}10 \\
15.6\end{array}$ & $\begin{array}{l}0 \\
0\end{array}$ & $\begin{array}{l}0 \\
0\end{array}$ & 3.84 \\
\hline 4. & $\begin{array}{l}\text { Given the right training and } \\
\text { resources, I intend to use the ERMS } \\
\text { in my current work }\end{array}$ & $\begin{array}{l}52 \\
81.3\end{array}$ & $\begin{array}{l}12 \\
18.8\end{array}$ & $\begin{array}{l}0 \\
0\end{array}$ & $\begin{array}{l}0 \\
0\end{array}$ & 3.81 \\
\hline
\end{tabular}

Table 7 Descriptive Analysis of Perceived Job Relevance of the ERMS

(Source: Researcher's Field Results, 2020)

\begin{tabular}{|c|c|c|c|c|c|c|}
\hline $\mathbf{S} / \mathbf{N}$ & Statements & $\begin{array}{l}\text { SA } \\
\mathbf{N} \\
(\%)\end{array}$ & $\begin{array}{l}\mathbf{A} \\
\mathbf{N} \\
(\%)\end{array}$ & $\begin{array}{l}\mathbf{D} \\
\mathbf{N} \\
(\%)\end{array}$ & $\begin{array}{l}\text { SD } \\
\mathbf{N} \\
(\%)\end{array}$ & Mean \\
\hline 1. & $\begin{array}{l}\text { I will use the ERMS due to } \\
\text { its relevance to my job } \\
\text { roles }\end{array}$ & $\begin{array}{l}50 \\
78.13\end{array}$ & $\begin{array}{l}14 \\
21.87\end{array}$ & $\begin{array}{l}0 \\
0 \\
0\end{array}$ & $\begin{array}{l}0 \\
0 \\
0\end{array}$ & 3.78 \\
\hline 2. & $\begin{array}{l}\text { Due to benefits that I } \\
\text { derived after using the } \\
\text { ERMS, I strongly see the } \\
\text { need for its use by } \\
\text { LASEMA }\end{array}$ & $\begin{array}{l}54 \\
84.38\end{array}$ & $\begin{array}{l}10 \\
15.63\end{array}$ & $\begin{array}{l}0 \\
0\end{array}$ & $\begin{array}{l}0 \\
0\end{array}$ & 3.84 \\
\hline
\end{tabular}

A test for any significant difference between the Control Group and the Experimental Group during the pre-test phase, as shown in Table 8, showed there was no significant difference between the Control group and the Experimental group in all the variables at $p<.05$, during the Pre-Test phase.

Table 8: Summary of Hypothesis Testing (Pre-test) (Source: Researcher's Field Results, 2020)

\begin{tabular}{|l|l|c|c|c|}
\hline S/N & \multicolumn{1}{|c|}{ Items } & $\begin{array}{c}\text { Control Group } \\
\text { (Mean) }\end{array}$ & $\begin{array}{c}\text { Experimental Group } \\
\text { (Mean) }\end{array}$ & Test of Significance \\
\hline $\mathbf{1}$ & $\begin{array}{l}\text { Perceived Ease of Use of the } \\
\text { Emergency Response } \\
\text { Management System }\end{array}$ & 2.814 & 2.719 & $\begin{array}{c}P=.104>.05 \\
\text { No significance }\end{array}$ \\
\hline $\mathbf{2}$ & $\begin{array}{l}\text { Perceived Usefulnes (PU) of } \\
\text { the Emergency Response } \\
\text { Management System }\end{array}$ & 2.914 & 3.021 & $\begin{array}{c}P=.234>.05 \\
\text { No significance }\end{array}$ \\
\hline $\mathbf{3}$ & $\begin{array}{l}\text { Attitudes Towards Use (ATU) of } \\
\text { the Emergency Response } \\
\text { Management System }\end{array}$ & 3.326 & 3.198 & $\begin{array}{c}P=.557>.05 \\
\text { No significance }\end{array}$ \\
\hline $\mathbf{4}$ & $\begin{array}{l}\text { Behavioral Intention to Use } \\
\text { (BIU) of Effective Emergency } \\
\text { Response (ERMS) }\end{array}$ & 3.135 & 3.27 & $\begin{array}{c}P=.414>.05 \\
\text { No significance }\end{array}$ \\
\hline $\mathbf{5}$ & $\begin{array}{l}\text { Job Relevance (BIU) of } \\
\text { Effective Emergency Response } \\
\text { (ERMS) }\end{array}$ & 3.245 & 3.301 & $\begin{array}{c}P=.09>.05 \\
\text { No significance }\end{array}$ \\
\hline
\end{tabular}


At the post-test phase, a test for any significant difference between the Control Group and the Experimental Group, as shown in Table 9, showed there was a statistical significant difference between the Control group and the Intervention group in all the variables at $\mathrm{p}>.05$.

Table 9: Summary of Hypothesis Testing (Post-test)

(Source: Researcher's Field Results, 2020)

\begin{tabular}{|l|l|c|c|c|}
\hline $\mathbf{S} / \mathbf{N}$ & Items & $\begin{array}{l}\text { Control } \\
\text { Group } \\
\text { (Mean) }\end{array}$ & $\begin{array}{c}\text { Experimental } \\
\text { Group } \\
\text { (Mean) }\end{array}$ & Significance \\
\hline $\mathbf{1}$ & $\begin{array}{l}\text { Perceived Ease of Use of the } \\
\text { Emergency Response Management System }\end{array}$ & 2.854 & 3.78 & $\begin{array}{l}P=.000<.05 \\
\text { Significance }\end{array}$ \\
\hline $\mathbf{2}$ & $\begin{array}{l}\text { Perceived Usefulness (PU) of the } \\
\text { Emergency Response Management System }\end{array}$ & 2.814 & 3.81 & $\begin{array}{c}P=.002<.05 \\
\text { Significance }\end{array}$ \\
\hline $\mathbf{3}$ & $\begin{array}{l}\text { Attitudes Towards Use (ATU) } \\
\text { of the Emergency Response Management } \\
\text { System }\end{array}$ & 3.626 & 3.85 & $\begin{array}{l}P=.011<.05 \\
\text { Significance }\end{array}$ \\
\hline $\mathbf{4}$ & $\begin{array}{l}\text { Behavioral Intention to Use (BIU) of Effective } \\
\text { Emergency Response (ERMS) }\end{array}$ & 2.735 & 3.83 & $P=.001<.05$ \\
\hline $\mathbf{5}$ & $\begin{array}{l}\text { Job Relevance (BIU) of Effective Emergency } \\
\text { Response (ERMS) }\end{array}$ & 2.845 & 3.81 & $\begin{array}{l}P=.012<.05 \\
\text { Significance }\end{array}$ \\
\hline
\end{tabular}

\section{CONCLUSION}

In this paper, a new emergency response management system was develop to enhance the present functionalities of the existing system at the Lagos State Emergency Management Authority (LASEMA). It works on the assumption that all the existing response sub-stations in Lagos State are inter-connected, for ease of communication, to the central Control Room. This helps to ensure a smooth incident command system of operation.

The new system is a composite of a mobile application at the front-end, running on Android smartphones while at the back-end is a web-based server application. To evaluate the response time functionalities of the new system, it was implemented in phases using at each phase a unique short path algorithm.

Based on the implementation runs of the ERMS, the Ant Colony Optimization recorded the fastest response time better than the other short path algorithms used in this work (Dijkstra; Suurballe; and Bellman Ford). Also, based on the evaluated tests of significance, the new ERMS optimized resources and travel routes, and also improved serviceability and efficiency over the existing response management system at LASEMA.

\section{REFERENCES}

[1] Dorigo M, Maniezzo V, Colorni A. (1996). Ant System: Optimization by a colony of cooperating agents. IEEE Trans Syst Man Cybernet Part B 1996; 26 (1):29-41.

[2] Dorigo, M. (1992). Optimization, Learning and Natural Algorithms; a PhD Thesis, Politecnico di Milano, Italy 1992.
[3] Dorigo M. \& Stützle T. (2002). The ant colony optimization metaheuristic: Algorithms, applications and advances. In F. Glover and G. Kochenberger, editors, Handbook of Metaheuristics. Kluwer Academic Publishers,

[4] Dwiputranti Made Irma, Oktora Adriyani, Okdinawatt Jane, Fazan M Nurkamal (2019). Acceptance and Use of Information Technology: Understanding Information Systems for Indonesia's Humanitarian Relief Operations; Gadjah Mada International Journal of Business, Vol. 21, No. 3 (September-December 2019): 242-262Retrieved from https://lasema.lagosstate.gov.ng/

[5] Lazarowska, A., (2014). Ant Colony Optimization based navigational decision support system, in Procedia Computer Science, 35, 1013 - 1022.

[6] Lihan Lihan (2017). An Application on Mobile Devices with Android and IOS Operating Systems Using Google Maps APIs for the Traveling Salesman Problem; Applied Artificial Intelligence; 31:4, 332-345. DOI: 10.1080/08839514.2017.1339983, ISSN: 0883-9514 $1087-6545$ http://www.tandfonline.com/Ioi/uaa120

(Online)

[7] Marco Darigo, Mauro Birattari and Thomas Stutzle (2006). Ant Colony Optimization; an Article Publication in IEEE Computational Intelligence Magazine December 2006; DOI.10.1109/MCI.2006.329691

[8] Marco Darigo and Thomas Stutzle (2014). The Ant Colony Optimization Meta-heuristic: Algorithms, Applications, and Advances; a Technical Report IRIDIA-2000-32

[9] Mikel Fagel and Greg Benson (2016). A Golden Hour of Disasters: The Road to Recovery; A Presentation at ASIS Orlando 2016 


\section{A Prototype Web-Based Emergency Response System That Incorporates the Findings from the Shortest Route Techniques for Path Optimization}

[10] Shyama, K., \& Kumar, P. N. R., (2015). On the amenability and suitability of Ant Colony Algorithms for Convoy Movement Problem, in Procedia - Social and Behavioural Sciences, 189, 3 - 16.

[11]Tomera, M., (2014). Ant colony optimization algorithm applied to ship steering control, in Procedia Computer Science, 35, $83-92$.

[12]Vimala Nunavath. Andreas Prinz; \& Tina Comes (2016). Identifying First Responders Information Needs: Supporting Search and Rescue Operations for Fire Emergency Operations; International Journal of Information Systems for Crisis Responses and Management, 8(1).

[13]Vinson F. (2013). Top 10 Reasons why mobile qtechnology is more important than ever. Retrieved http://localorganicrankings.com/top-10-reasons-whymobile-technology-is-more-important-than-ever/ 